\title{
The Morality and Utility of Alternative Dispute Resolution in the Nigerian State
}

\author{
Ephraim Ahamefula Ikegbu, Abel Idagu Ushie \\ Department Of Philodophy University Of Calabar, Calabar - Nigeria
}

\begin{abstract}
Arguably, prominent scholars in the ancient, medieval, modern and contemporary periods in human existence had argued to the conclusion that no one is self sufficient, implying that everyone at anytime needs the cooperation of everyone for the continuous existence of life. The advancement of this cooperation and its sustenance by people of diverse culture, religions, languages, ethnic and socio-political backgrounds may result to disagreement and other violent dispositions which act, if not checkmated could cause monumental disruptions, economic collapse and inter and intra ethnic clashes. The necessity of human existence cannot be over emphasized as this would ensure political and economic prosperity of a nation state such as Nigeria. It is in the light of ensuring convivial atmosphere, balanced and valid socio-cultural fraternity and inarguable insufficiency of human wants that it becomes moral and utilitarian for leaders of state and organization to utilize the facilities of alternative dispute, for resolution of conflicts and disagreement that may arise in the cause of their private and public relationships. The morality of alternative dispute resolution is hinged on inelastic protection of parties from public knowledge, economic value and peaceful and transparent restoration of confidence in friendship.
\end{abstract}

Keywords: Morality, Utility and Dispute Resolution.

\section{INTRODUCTION}

Nigerian state is a conglomerate and composite of males and females from diverse ethnic - religious, linguistic and cultural backgrounds craving for a well developed, meaningful, purposeful political order where peace and tranquility prevail to an enviable degree. It is a state characterized with abundance of human and natural resources, serene and friendly environmental ecosystem that attracts and propel investments in varying degrees. The friendly and accommodating investment climate motivate a wide range of investors from national, regional, continental and international flavour to have a taste of what it has to offer for them. These investments drive and abundance of economic opportunities are inroads and formidable gateway for social fraternity, exchange of business ideals, multicultural assimilation, behavioural tolerance and conflicts. Ozumba and Ikegbu argued that:

Humans are products of evolutionary process and mutual complementary unity upon which progress and developments are realized. It is markedly observed that it is practically impossible at least for now to live a life of isolation since attempting such obvious difficulty would retard the mental and economic development of beings in the practical world of existence (4).

Appreciating the above, goes to suggest that humans need the interactions and cooperation of one another for the continuity of the race of existence. This been the case, incidences of conflicts, violence, disagreements, mamining and monumental crises that are capable of collapsing this obvious existing social, economic, religious, political and cultural fraternity are better and prudentially resolved using the facilities of alternative dispute resolution. The moral and utilitarian dimensions of alternative dispute resolution are in threefold and more. On the one count, it ensures a friendly reconciliation and restoration of the art of friendship in the specific aspect of relationship and in other dimensions. On the second count, it protects and preserves the warring and conflicting parties from public knowledge and castigation as parties and mediators have a protective fiduciary understanding. On the third count, it saves cost and does not sap the resources of the conflicting parties unlike the orthodox dispute resolution mechanism such as the courts. This is why the investment of time and resources investigating and recommending a faithful application of alternative dispute resolution by the leadership of Nigerian State has become very necessary and expedient.

\section{UNDERSTANDING THE CONCEPTS OF MORALITY, UTILITY AND DISPUTE RESOLUTION}

Morality: Morality is derived from the study of ethics which borders on the rightness and wrongness of one's actions so as to determine whether or not the action is in tandem with the approved conduct by the society. Anthony O. Echekwube defined ethics and/or morality to mean:

DOI: $10.9790 / 0837-2205040107 \quad$ www.iosrjournals.org $\quad 1 \mid$ Page


The scientific study of the behavioural patterns of the human person with special references to his or her nature as a rational being. Ethics seeks to device reasons for approving or condemning human acts as right or wrong, good or bad, and as worthy or unworthy of a rational being ... premium is given to human freedom, which is closely aligned with human rationality (Kpim of morality, 29)

What could be deduced from the above is that the concern of morality is to determine and evaluate human conducts in order to decipher conducts that are appropriate and inappropriate in a given society. When one's conduct falls short of the expectations of the public, such conduct will be inappropriate and immediately be condemned. Perhaps, this caused Socrates to declare in his dicta that "unexamined life is not worth living" and "man know thyself".

The society as a complex institution with varying and diverse cultural orientation prohibits acts that would further advance the complexity of network of operations. Moral reasoning and rational dispositions will necessarily galvanize commonality of interest and purpose and bring parties to moral uniformity. This is necessary judging from the above dicta by Socrates. One's actions and inactions are to be judged and evaluated by oneself and determined strongly how positive impact such actions are creating on the lives of people. If such conducts are not of any moral consequence and value, it becomes completely out of place to carry out or continue with such acts.

The society therefore, in its wisdom approves conducts that will impact positively on the lives of members, conducts that will navigate the process of communal living, harmonious fraternity and tolerance. This as stated above is what morality borders itself with. The society and its members should endeavor to tolerate one another, appreciate each other, complement each other and find a common ground to propagate the sermon of peace and tranquility for mutual benefit.

\section{UTILITY}

The concept utility or utilitarian in this context refers to value, the good and necessity of a thing. Utilitarianism as a philosophical coinage and vocabulary is linked to Jeremy Bentham, James Mill, John Austin, and J. S. Mill. Utilitarianism as a school of thought, originated in English in the earlier half of nineteenth century. It was taken by the philosophical radicals that came up with a compendium of programme of legal, economic and political reforms linking it with the doctrine of the greatest happiness of the greatest number.

Historically, utilitarian philosophy was a product of English tradition in psychology packaged by Locke and Hume. According to V. D. Mahajan, "its beginnings appeared in the seventeenth century in the writing of Richard Cumberland 1632-1719) who regarded general welfare as the highest good ... the formula of the greatest happiness of the greatest number was first used by Francis Hutcheson (1694-1747) (654). The underlying philosophy governing the principle of utility is that all men desire pleasure and do everything humanly possible to avoid pain. All acts that attract pleasure and happiness should be encouraged and longed for, while all acts that cause pain and displeasure are to be avoidable with utmost care. With this understanding, truth and morality seem not to have any other meaning. A thing is simply adjudged to be true if it promotes happiness. The happiness of the member of a given society should be sought for and promoted, while those things that would endanger their happiness and put them in a state of pain and misery should be avoided.

Moral acts are value-laden and utilitarian too, because such acts promote the welfare and happiness of the greatest number of the people. To buttress this position, Jeremy Bentham has argued:

Nature has placed mankind under the government of two sovereign masters, pain and pleasure; it is for them to point out what we ought to do. The only criticism to measure virtue and vice is pleasure and pain. If we derive pleasure from an action, that is a good action and if we get pain from it, it is a bad action. Good work is worth doing and bad action is to be discarded (Benthem cited by V. D. Mahajan, 658). Humanity or society desires good work, happiness of the soul and serene atmosphere that is why good actions are encouraged and bad ones are discouraged. Peacemaking, resolution of conflict and disregard of acts of violence are actions intended to promote unity and socio-economic prosperity of a nation state. They are acts intended towards the benefit of the greatest number of the population. Acts of utility are therefore, value-laden moral creeds that seek to promote unity, peace, progress and socio-economic growth of every segment of the society. Utilitarian acts are pursued with vigour due to their avowed benefits and position as healing balm for continuous human existence.

\section{DISPUTE RESOLUTION}

The term dispute implies no less than a verbal controversy, conflict or disagreement between two or more persons over an object of interest. It can also be seen as a misunderstanding, bicker, altercation, quarrel, argument and/or squabble ranging between and among two or more persons over an object of interest. Webster's dictitimary defines it to mean "verbal controversy, verbal conflict between antagonists" (185). Dispute is a tendency in man/women to rise to a disagreement with another person over an issue which if not controlled, may lead to fight and evident collapse of the system. One ugly phenomenon about dispute is that, it could escalate to a very dangerous degree which may cause monumental havoc to the system. Uncontrolled and untamed dispute 
may wipe an entire generation. This is why no dispute should be regarded as small, but should rather be nipped in the bud the moment it is about to start. Dispute can also, be regarded as conflict. It is an acknowledged norm all over the world to live in a peaceful environment. This is why conflict or dispute resolution management and prevention is encouraged because of the necessity of living together in a given society.

Alternative dispute resolution (ADR) was introduced and advanced because of its moral and utilitarian posture of ensuring continuity of friendship, protection and preservation of personal integrity from public knowledge, and its non-violent approach. The pattern is widely acknowledged in the family, group, community national and international levels. Shedrack Gaya Best responding to the need or better methods of conflict resolution and transformation identified two strands for a peaceful conflict resolution which he regarded as proactive category and reactive category (93). According to him;

The first is the proactive category which entails methods that aim to prevent the occurrence of conflict in the first instance. Examples include undocumented community based trust and confidence building measures, communication, good governance, inter-party collaboration etc. The second category is reactive, dealing with response to situations that have already turned conflictive or are potentially so. These include the third party interventions like mediation brokerage. Conciliation. Arbitration and litigation, etc. (93-94).

Very connected to the above on conflict resolution is the position of Michael and Banks that conflict resolution refers to:

(i)An outcome in which the issues in an existing conflict are satisfactorily dealt with through a solution that is mutually acceptable to the long run and production of a new, positive relationship between parties that were previously hostile adversaries; and (ii) any process or procedure by which such an outcome is achieved (cited by Shedrack Gaya Best, 94 ).

A cursory look and careful study of what is captured in (i) above will appreciate the morality of dispute resolution. This is premised on the fact that warring parties or conflicting parties are made to come together under a mutually acceptable grounds. The parties hitherto in conflict are reunited, and begin to interact, cooperate and co-exist leaving behind those things that were the sources/cause of their friction.

\section{STRANDS OF ALTERNATIVE DISPUTE RESOLUTION}

It is a truism that global peace and harmony cannot be compromised. Aligning with the necessity of global peace and harmony, Ozumba and Ikegbu argue that:

Peace remains and continues to be a well sought moral virtue for every living organism. It is sacred and significant, adequately-treasured phenomenon upon which its absence is quickly observed, and constitutes a dislocation in the entire framework of existence. Human beings, animals (domestic and wild), plants and other lives (aquatic and terrestrial) appreciate the sanctity of peace. Peace navigates development and accelerates monumental growth in human beings, animals, states and nations (71).

From the point of view of Ozumba and Ikegbu as stated above, any effort(s) made towards achieving peace and/or resolving conflict remains efforts in a right direction. However, this paper shall examine the following strands of alternative dispute resolution.

1. Communication: This implies the process of exchanging information between and among parties involved in a conflict. This process affords parties the opportunity to eliminate suspicion and doubts and create room for parties to exercise confidence in themselves. Poor communication or lack of it is injurious to a system. It damages relationship and sends wrong signal. There should be forum for discussion of the subject matter of the conflict, parties should be able to appreciate their faults when pointed out and communicated to them. When this is done, fear is gone, lifestyle adjustments are made and conflicting psychology is eliminated. It is quite moral for people in a conflicting situation to talk and discuss their differences for possible resolution.

2. Negotiation: This in this context implies the process by which parties in a conflicting situation are meant to deliberate on issues of varying opinions. Fisher et al defines negotiation to mean "a structured process of dialogue between conflicting parties about issues in which their opinions differ" (115). Also, the trio of Miall, Ramsbotham and Woodhouse understood and define negotiation to mean "the process whereby the parties within the conflict seek to settle or resolve their conflict" (21).

Indeed, negotiation takes the shape of a direct contact and discussion between two or more persons in a conflict seeking for a proper way of settling their disputes. They acknowledge the fact that there is an existing problem amongst them and make effort to resolve same. When there is negotiation, it gives room for compromise, and this is more beneficial than the losses that may arise as a result of failure to negotiate.

In fact, it is more appropriate to enforce the facilities of negotiation when communication is still possible, which is at the early stage of the conflict. If communication is threatened, it becomes apparently difficult to negotiate. It is always morally advisable to commence action early enough and get parties back to their reasoning track.

Only parties in conflict are open to negotiation. It does not involve third party. The compromise reached is as a result of the discussions held by them. 


\section{Conciliation:}

Christopher Miller citing the University for Peace defines conciliation to mean:

The voluntary referral of a conflict to a neutral external party (in the form of an unofficial commission) which either suggests a non-binding settlement of conducts explorations to facilitate more structures of techniques of conflict resolution. The later can include confidential discussion with disputants or assistance during a prenegotiation phase (Miller, 6-7).

From the above explanation, the conciliator in an attempt to resolve the conflict takes the step of speaking to the conflicting parties separately. The wisdom and logic behind separate communication is to avoid parties coming together at that moment, and also to reduce tension that would have escalated should parties be allowed to exchange words.

Conciliation has both moral and utilitarian value, because, the whole exercise is geared towards bringing the parties back again as friends. The neutral umpire exudes confidence and competence to resolve the conflict demonstrating unbiased and absence of prejudicial flavour in the exercise. The conciliator eliminates all forms of pecuniary interests and approaches the task of resolving the conflict with vigor.

4. Mediation: The science of mediation rests on the conscious exercise and exhibition of intervention by a third party who voluntarily undertakes to carry out the project. According to Miall, Rambotham and Woodhouse, mediation is defined as The intervention of a third party; it is a voluntary process in which the parties retain control over the outcome (pure mediation) although it may include positive and negative inducements (mediation with muscle) (22).

Mediation takes place upon an invitation to the third party by the conflicting parties admitting the existence of conflict between them which they are incapable of resolving, and on which the assistance of impartial and neutral third party is needed. As a voluntary service, the concern of the mediator is to demonstrate readiness in restoring peace and friendly atmosphere among the parties. In discharging this task, he does it without fear or favour. The mediator makes sure that the parties arrive at a common ground for peace to reign among the parties.

5. Arbitration: The decision of a neutral third party who is called upon by the conflicting parties for a peaceful resolution of the conflict is usually binding on the parties. The arbitrator fearlessly finds himself on top of the situation and becomes a quasi judge for the resolution of the conflict between the parties involved.

Shedrack Gaya defined arbitration as:

The use and assistance of a neutral third party in conflict, who hears the evidence from both parties, and thereafter renders a decision, usually called award, which is expected to be binding on parties (108).

Arbitration is closely related to adjudication but different from mediation. In mediation, decisions reached do not have binding force in parties. However, in arbitration, enforcement of decisions reached is different from litigation. Arbitration is done outside the courts. In legal jurisprudence and administration of justice, there is a widespread recognition of the morality and utility of arbitration clause in resolving disputes. Once parties in a transaction elect to report to arbitration in the settlement of any dispute that may arise in their transaction, the facility of arbitration and other related dispute resolution mechanisms must be exhausted before going to the open courts as the final arbiter. Where either of the parties fails in recognizing this clause, it will bring to nullity the existence of the case in an open court.

Arbitration as an alternative dispute resolution mechanism is a product of consent of the parties. It does not imply that a dissatisfied party cannot approach the open court for proper redress of his/her grievances, but the facilities of arbitration as contained in the contract relationship must be exhausted before seeking for alternative approach.

For proper elucidation, Nigeria's arbitration clause 2004, is hereby reproduced:

Whereas disputes have arisen between the parties to an agreement for the construction of ... dated the.............day of............ 2017 and the parties have agreed to refer these disputes to be finally settled by arbitration.

\section{NOW IT IS AGREED AS FOLLOWS ...}

Litigation: this is another dispute resolution mechanism which is universally and commonly applied. It is the use of court processes in resolving a dispute. Parties to a business transaction or parties to a dispute may ignore the strands of dispute resolution discussed earlier and decide to approach the open court for the resolution of their dispute. Only courts of competent jurisdiction are allowed to handle such disputes.

The nature of disputes determine whether a particular court of law has jurisdiction to hear/entertain the dispute or not, where a matter is wrongly filed in a court that lacks jurisdiction to entertain the case, the case will be struck out for want of jurisdiction. And if the court goes ahead to entertain the case in spite of clear evidence of lack jurisdiction, the court's decision may be challenged subsequently by a higher court and decisions 
previously reached will be upturned. Parties to dispute who decide to go far litigation for the settlement of their dispute are at liberty to seek for legal representation. By so doing, they will take care of the legal fees, and shall also, abide by the decision of the judge by way of judgment. Where either of the parties is dissatisfied, the dissatisfied party can go on appeal to a higher court. However, it must be noted that while not dispelling the utility of litigation in resolving dispute, it usually does not restore the much expected confidence, love and trust that would have been the goal of other strands of dispute resolution mechanism.

This is because, the expressed attitude in litigation is the win-lose attitude. The winner goes home with love, happiness and celebrative mood and the loser gets nothing but a painful and sorrowful mood. This situation will certainly or may cause a generational crisis between the parties especially, when the loser remembers the huge sums of money expended without success; the winner, even though, he goes home happy, may feel pain realizing the agony, frustration, financial loss and other inconveniences encountered while going through litigation processes. A discomforting phenomenon in litigation is the fact that a party cannot determine the length of time that the case would last in court.

\section{ALTERNATIVE DISPUTE RESOLUTION IN THE LEADERSHIP OF THE NIGERIAN STATE}

Since the dawn of democratic rule in may 29, 1999 in Nigeria after a prolonged military rule, incidences of conflict and violence have erupted which have consequently interrupted socio-political and economic activities and slowed down developmental pedestal in the Nigerian State. The activities of the Niger Delta Militia, The Movement for the Sovereign Sstate of Biafra (MASSOB), Movement for the Survival of Ogoni People (MOSOP), the Modakeke, the Odua People Congress, the Boko Haram and most recently, the Fulani Herdsmen, have attacked the smooth running of the Nigeria state. There is also, in existence, the Christian - Moslem clash which has affected the country adversely.

Any country faced with high-level conflict and violence cannot really do well in all the spheres of existence. Task for instance, human and material resources so wasted in the carnage and act of terrorism that is occurring in Nigeria today has become unbearable. This ugly phenomenon is indeed a challenge to the sovereignty of Nigeria and a threat to democracy. Wanton destruction of lives and property, vandalization of oil pipelines and other installations, burning of churches and other private and government owned properties is an indication that peace and tranquility have elected the Nigeria state. It could also, be an indication that government of the day has lost full control of the sovereignty of the state at both sides of the picture.

The danger in violence and conflict is that it takes the country, state, community and family backwards with dangerous and ugly psychology, the wasted human resources and materials cannot be recovered no matter the efforts people may inject in this direction. The necessity of peace and conviviality that are required for effective leadership and provision of social amenities for the mass of the people precipitated the global campaign for peace and alternative means of resolving disputes in the human society. For instance, due to the activities of miscreants in the name of Boko Haram, Herdsmen and Niger Delta Militia, hundreds of thousands of Nigerian citizens have been displaced, their houses burnt and many of them died in the process.

The kidnapping of about 280 students of the Chibok Girls in Maiduguri, Borno State in April $14^{\text {th }}, 2014$ by the Boko Haramists is still fresh in the minds of Nigerian people. The agony and trauma those little children had gone through in the hands of their adductors is better imagined. Today Millions of Nigeria's hard earned money had been spent on rehabilitation of the released Chibok girls maintenance of the internally displaced person (IDP) and their caps and other money spinning ventures undertaken to resuscitate the lives of the unfortunate persons abducted. Just recently, about 10 students and staff of the Nigeria Turkish school, Ogun were kidnapped and ransom demanded by the kidnappers before their release could be effected.All these ugly incidence point to the collapse of the system, Acts terrorism and crimes have taken over the leadership of the Nigerian government. Apart from violence orchestrated by criminally minded people, conflicts and violence have also occurred and are occurring due to government's inability to demonstrate faithfulness in an attempt to resolve them. Take the case of the labour unions and trade unions in Nigeria. There has been series of conflicts between Academic Staff Union of Universities (ASUU) and Federal Government of Nigeria over nonimplementation of agreements and memoranda freely reached and entered by both parties. The nonimplementation of these agreements has affected the smooth running of academic calendar thereby causing dislocation in the system. For instance, the 2009 ASUU - FGN agreement has not been fully implemented; its renegotiation which is one of the components of the signed agreement has not taken place. Apart from ASUU, the Academic Staff Union of Polytechnics (ASUP) is also on a faceoff with the government. For instance, The National Association of Resident Doctors (NARD), National Union of Petroleum and Natural Gas Workers (NUPENG) Petroleum and Natural Gas Senior Staff Association of Nigeria (PENGASSAN), Nigerian Labour Congress (NLC) and other have had several disputes ranging from condition of service, general welfare of workers, policy framework and other unfriendly policies of government such as increment on petroleum products privatization of government owned estates, wage adjustment, rationalization and reduction in work 
force. Controversies and disputes generated as a result of government's hardline approaches are usually talked down on round table through the process of negotiation; communication, mediation, conciliation and other networks of dispute resolution mechanism. Sadly, the Nigerian leadership is more of a theoretical leadership than practical and proactive leadership. This is premised on the fact that decisions reached as a result of prolonged negotiation, mediation and conciliation are usually breached by the same government that entered and signed such agreements disregarding their corresponding consequences.

Between 2006 down to 2010, the administration of Alhaji Umaru Musa Yar'Adua was heavily threatened by the activities of the Niger Delta militia, Oil facilities were vandalized by the militants and this ugly phenomenon affected the economic activities of the country as oil production dropped to alarming stage.

Both the Egbesu Boys, the Niger Delta Volunteer Force (NDVF), Mosop, the Government Tompolo Boys and the Asari Dokubo boys were all out to achieve their parochial gain of crippling the economy. However, the government of Yar'Adua realizing the importance of the regime, engaged them on a discussion-a principle of communication and negotiation, a veritable instrument for conflict resolution was utilized and Amnesty policy was introduced and granted to them that agreed to put a stop to military.

Again, the non-continuation of the amnesty policy or gradual withdrawal of government's commitment has equally made the region a theatre for violence. Indeed alternative dispute resolution mechanism is so vital and central for recognition in any contractual arrangement between parties, to the extent that the ADR components must be fully observed before approaching the out-of-ADR component for resolution of dispute such as approaching an open court. No less authority to buttress the above position than the expression and ruling of the judge of National Industrial Court (NIC), Calabar Division in the case between Peter Agi and the Vice Chancellor of the University of Calabar (unreported). In the said ruling, the judge declared that he lacked jurisdiction to hear the matter due to the inability of the plaintiff to exhaust the ADR facilities open to him before approaching the open court which in the wisdom of the judge was the last resort and a violation of the principle (unreported).

The expression of the judge was anchored on the morality and utility of alternative dispute resolution, a friendly, protective and cheaper method of settling disputes. It is both moral and value-laden for people especially, the leadership class to keep to the terms of agreement and avoid the use and application of federal might to suppress one's opinions and rights.

Alternative Dispute Resolution is s morally and utility-based acknowledged method of resolving conflicts all over the globe. In fact, it is so central and unique that those in the legal profession have to adopt it as a significant step which must be followed and evidence shown before appearing in the open court. This is necessary because, humanity wants to live at peace and fraternize with its neighbors for continuity of existence. His is not possible in an atmosphere of conflict and rancor.

This paper therefore, having $\mathrm{x}$-rayed the necessity of peace and harmonious living in a given community, and having realized that no one can exist alone which corroborates the expressions of Aristotle and Ozumba and Ikegbu as referenced above, the leadership of the Nigerian state should inculcate the character of peaceful negotiation, mediation, conciliation and other dispute resolution mechanism than the resort to federal might.

It is also observed that non-observation and implementation of the components of agreements by the leadership class which is a product of thorough peaceful collective bargain, negotiation, conciliation and mediation could be linked to conspiracy factor. Conspiracy factor in this context and in the context to which Ikegbu applies it earlier is the tendency by which a person or group of persons conspire with another person or group of persons to work against the policy framework of a government, organization, association or society for selfish and parochial gains.

Some "elements" in the government circle may conspire with a common intention and purpose to see that agreements freely entered by government are not obeyed. They may advise government wrongly so as to advance their own interest thereby inhibiting the process of peace and constantly sowing seeds of discord, industrial disharmony, inter and intra ethnic and religious disunity.

\section{CONCLUSION}

This paper has carefully examined the need for people of diverse cultures, religions, languages and behavior to continue to fraternize and carry out their socio-economic activities without hindrance either natural, artificial or systemic. The paper has argued that in the events of commonality of social interactions and advancement of economic activities, conflict and conflicting dispositions and tendency may arguably occur. It is the wisdom and logic of this paper that rather than resorting to the facilities of open court which does not protect the integrity of parties for the resolution of conflicts, alternative dispute resolution mechanisms should be judiciously and expeditiously applied.

The morality and utility of alternative dispute resolution mechanism is in three fold viz; on the one hand, it ensures a friendly reconciliation and restoration of the art of friendship in the specific art of relationship; 
on the second hand, it protects and preserves the conflicting parties from public knowledge and castigation, and on the third strand, it is economy friendly.

This paper therefore recommends that the leadership of the Nigerian state should take proactive and practical steps to apply the principles of alternative dispute resolution mechanism which will achieve results faster, build bridges of confidence and play protective role to parties as no victor nor vanquish is better than the winner - loser phenomenon that characterize the open court system of conflict resolution.

\section{WORK CITED}

[1]. Echekwube, Anthony O. "What is Ethics? Definitions, Principles, Theories, and Relationship to other Disciplines", Kpim of Morality: Ethics, general Special and Professional. Pantaloon Iroegbu and Anthony Echekwube (Eds) Ibadan: Heinemann Educational Books, 2015, (29-35).

[2]. Ikegbu, Ephraim and Sunday A. Duru. Nigerian legislature and self esteem: A case for Part-Time Legislature. Journal of integrative humanism-Ghana. Vol. 3, No. 1, (2013), 101-119

[3]. Mahajan, V. D. Political Theory. New Deihi: S Chand \& Company 2008.

[4]. Miall, Hugh, Ramsbothan, Oliver and Woodhouse, Tom. Contemporary Conflict Resolution: The Prevention, Management and Transformation of Deadly Conflicts. Cambridge: Polity Press, 1999.

[5]. Miller, Christopher A. A Glossary of Terms and Concepts in Peace and Conflict Studies. Geneva: University for Peace, 2003.

[6]. National Industrial Court Ruling of $17^{\text {th }}$ January, 2017 (Unreported).

[7]. Ozumba, Godfery O, and Ephraim A. Ikegbu. "The Insufficiency of Humans and the Logic of Complementarity in the $21^{\text {st }}$ Century". Journal of Integrative Humanism-Ghana, Vol. 2, No. 1, 2012, 419.

[8]. Ozumba, Godfery O. and Ephraim A. Ikegbu. Intercultural / Intertribal Marriage: A Necessary tool for Peace Building among Nations. Integrative Humanism Journal, Vol. No. 1, 2011, (70-80).

[9]. Schedrack. The Methods of Conflict Resolution and Transformation". Introduction to Peace and Conflict Studies in West Africa. Ibadan: Spectrum Books, 2007, (93-115).

[10]. Shedrack, Gaya Best. Introduction to Peace and Conflict Studies in West Africa. Ibadan: Spectrum Books, 2007.

[11]. Webster, Merriam. Webster's All-in-One Dictionary \& Thesaurus. Massachusetts Press, 2008. 